\title{
Pengaruh E-Service Quality Terhadap Loyalitas Pengguna Aplikasi MyTelkomsel
}

\author{
Ali Ibrahim*, Felia Sonya Elisa, Jose Fernando, Lulu Salsabila, Nadya Anggraini, Siti Nur Arafah \\ Jurusan Sistem Informasi Fakultas Ilmu Komputer, Universitas Sriwijaya, Palembang, Indonesia \\ Email: 1,*aliibrahim@unsri.ac.id, ${ }^{2}$ feliasonya.elisa@gmail.com, ${ }^{3}$ joseyap123@gmail.com, ${ }^{4}$ lulusalsabila08@gmail.com, \\ ${ }^{5}$ nadiaanggraini20@gmail.com, ${ }^{6}$ sitinurarafah60@gmail.com \\ Email Penulis Korespondensi: aliibrahim@unsri.ac.id
}

Submitted: 20/12/2021; Accepted: 27/12/2021; Published: 31/12/2021

\begin{abstract}
Abstrak-MyTelkomsel adalah layanan berbentuk aplikasi yang dapat diakses secara mobile yang diluncurkan oleh pihak Telkomsel untuk memudahkan para pelanggannya, dimana aplikasi tersebut berbentuk self service untuk para penggunanya. Namun, aplikasi MyTelkomsel masih saja mendapatkan beberapa keluhan dari penggunanya, keluhantersebut seperti kegagalan dalam proses login, kegagalan dalam proses melakukan pembayaran/transaksi, jenis paket yang ditawarkan pada tiap device pengguna berbeda dan terkadang tidak sesuai dengan budget pelanggan, serta beberapa komentar dari pengguna mengenai customer service yang membuat mereka tidak puas. Tujuan dari penelitian ini yaitu untuk mengetahui apakah terdapat pengaruh e-service quality terhadap loyalitas pengguna pada aplikasi MyTelkomsel. Pada penelitian ini model yang digunakan adalah $E$ Service Quality. Metode Pengambilan data pada penelitian ini, menggunakan penyebaran kuesioner secara online kepada responden pengguna MyTelkomsel melalui bantuan dari media sosial untuk proses penyebaran. Sampel yang digunakan pada penelitian ini sejumlah 50 responden dari pengguna aplikasi MyTelkomsel. Adapun jenis teknik sampling yang digunakan pada penelitian ini adalah random sampling dengan menggunakan kriteria. Untuk proses analisis data dari penelitian ini menggunakan aplikasi SmartPLS dan SPSS. Adapun hasil dari penelitian menunjukkan bahwa e-service quality memiliki pengaruh yang signifikan terhadap loyalitas pelanggan aplikasi MyTelkomsel
\end{abstract}

Kata Kunci: E-Service Quality; Loyalitas Pengguna; MyTelkomsel

Abstract-MyTelkomsel is a service in the form of an application that can be accessed by mobile which was launched by Telkomsel to make it easier for its customers, where the application is in the form of self service for its users. However, the MyTelkomsel application still gets several complaints from its users, such complaints as failure in the login process, failure in the process of making payments/transactions, the types of packages offered on each user's device are different and sometimes do not match the customer's budget, as well as some comments from users. regarding customer servicethat makes them dissatisfied. The purpose of this research is to determine whether there is an effect of e-service quality on user loyalty in the MyTelkomsel application. In this research, the model used is E-Service Quality. Methods of collecting data in this research, using online questionnaires to MyTelkomsel user respondents through the assistance of social media for the dissemination process. The sample used in this research was 50 respondents from MyTelkomsel application users. The type of sampling technique used in this research is random sampling. For the data analysis process from this research using the SmartPLS and SPSS applications. The results of the research indicate that e-service quality has a significant influence on customer loyalty in the MyTelkomsel application.

Keywords: E-Service Quality; User Loyalty; MyTelkomsel

\section{PENDAHULUAN}

Perubahan yang terjadi di era globalisasi telah mempengaruhi kehidupan manusia, terutama pada kehidupan seharihari. Salah satu kegiatan yang sangat dipengaruhi yaitu kegiatan berkomunikasi. Tidak adanya batasan jarak pada saat ingin berkomunikasi sangat mempermudah jangkauan hingga ke tempat yang sulit untuk dijangkau. Pemanfaatan teknologi masa kini merupakan hal utama yang mempengaruhi kegiatan komunikasi seperti ini dapat terjadi. Istilah yang tepat untuk menyatakan kegiatan komunikasi dengan memanfaatkan teknologi adalah telekomunikasi. Menurut [1] telekomunikasi adalah proses yang dilakukan untuk mengirimkan informasi dari satu tempat ke tempat lainnya dengan memanfaatkan teknologi informasi. Seperti yang telah dijelaskan bahwa telekomunikasi merupakan bagian terpenting dan kebutuhan utama bagi semua umat manusia dengan tidak memandang jenis kelamin, umur, dan pendidikan. Dalam memanfaatkan telekomunikasi, tentu saja dibutuhkan sebuah perusahaan yang akan memfasilitasi kegiatan komunikasi dengan memanfaatkan teknologi ini, dan salah satu perusahaan yang paling terkenal di Indonesia dalam menyediakan layanan komunikasi berbasis teknologi adalah PT. Telekomunikasi Selular Tbk dengan produk mereka yaitu Telkomsel. Perusahaan ini bergerak pada bidang telekomunikasi seluler.

Menurut Kominfo dalam [1] Telkomsel merupakan perusahaandi Indonesia yang bergerak pada bidang telekomunikasi seluler yang mempunyai pelanggan terbanyak, Telkomsel didirikan pada tanggal 26 Mei 1995. Perusahaan ini selalu berupaya untuk meningkatkan pelayanan kepada pelanggan. Oleh karena itu, Telkomsel meluncurkan aplikasi mobile yang bernama MyTelkomsel.

Aplikasi MyTelkomsel merupakan cara efektif yang digunakan untuk memberikan pelayanan prima kepada para pengguna. Dengan menggunakan sistem self-service diharapkan para pengguna MyTelkomsel dapat merasakan kebebasan berinteraksi dengan aplikasi ini. Hal ini dikarenakan, aplikasi MyTelkomsel dilengkapi dengan fitur yang bervariasi seperti pengguna dapat melihat sisa pulsa dan kuota paket internet, membeli pulsa dan paket internet, mengakses layanan customer service online, dan lain sebagainya. Dari semua fitur yang memudahkan pelanggan, ternyata aplikasi MyTelkomsel masih mendapat keluhan dan respon negatif dari penggunanya. Keluhan utama yang dirasakan oleh pengguna adalah pada kualitas pelayanan. Saat pengguna mengalami masalah dengan aplikasi 
MyTelkomsel, respon yang dibutuhkan harus melewati waktu yang lama sampai pengguna mendapatkan jawaban terhadap permasalahan yang dialami. Bahkan seringkali, jawaban yang diberikan tidak sesuai dengan apa yang diharapkan pengguna dalam penyelesaian masalah sehingga tetap saja pengguna harus mendatangi kantor Telkomsel terdekat untuk menyelesaikan permasalahan yang dialami. Padahal, menurut Ngo dalam [1] kepuasan pelanggan merupakan hal yang penting untuk diukur karena memiliki dampak terhadap kinerja jangka panjang perusahaan dan juga perilaku pelanggan dalam melakukan transaksi atau pembelian.

Penelitian sebelumnya yang dijadikan referensi pada penelitian ini adalah penelitian [2] yang menyatakan bahwa Customer Relationship Management (CRM) mempunyai pengaruh signifikan terhadap loyalitas pelanggan. Selain itu, menurut [3] terbukti bahwa Customer Relationship Management dan Kualitas Layanan dapat bekerja secara bersama - sama dengan tingkat capaian sebesar 67,8\% terhadap kepuasan pelanggan. E-Service Quality adalah suatu teori yang dikembangkan dari kualitas layanan yang diberikan atau dilakukan suatu perusahaan melalui internet. Kualitas layanan merupakan salah satu faktor utama yang mendorong keberlanjutan suatu bisnis dan menjadi keunggulan pada perusahaan untuk bisa menjadi kompetitif [4]. Penilaian dalam e-service quality ini dapat diukur dari kemudahan dan kenyamanan yang diberikan oleh perusahaan kepada para pelanggannya melalui media internet. Kualitas layanan elektronik memiliki arti sejauh mana media online dapat memfasilitasi kegiatan-kegiatan seperti berbelanja, pembelian, penyediaan informasi, distribusi, serta kegiatan lainnya secara efektif dan efisien [5].

Dalam penelitian [6] disebutkan bahwa terdapat lima dimensi dalam E-Service Quality yaitu: (1) Interface Design, kemudahan dan kenyamanan saat menggunakan media seperti situs web atau aplikasi. (2) Trust, tingkat kepercayaan dari pelanggan terhadap layanan yang diberikan perusahaan secara jelas dan akurat. (3) Responsiveness, kemampuan untuk merespon atau melayani dengan cepat dalam membantu pelanggan jika terdapat suatu pengajuan pertanyaan atau masalah. (4) Reliability, fungsionalitas teknis dari suatu layanan atau situs yang dapat beroperasi dengan minim gangguan, dan keamanan layanan yang disediakan. (5) Personalization, kemampuan perusahaan dalam menyediakan suatu layanan secara personal yang sesuai dengan kebutuhan pelanggan. Kepuasan pelanggan dalam aplikasinya itu tergantung dari loyalitas merek yang memiliki beberapa indikator penilaian, diantaranya menjadi pilihan pertama, kesetian, berani membayar lebih. Apabila pelanggan semakin tinggi kepuasannya dalam menggunakan produk yang tersedia maka akan semakin baik loyalitas merek atau brand tersebut [7]. Loyalitas adalah suatu komitmen pelanggan atau pengguna untuk bertahan dalam melakukan pembelian ulang atau berlangganan kembali terhadap produk atau jasa secara konsisten di masa mendatang, walaupun dampak keadaan atau aktivitas pemasaran berpotensi untuk menyebabkan perubahan perilaku pelanggan [8]. Dalam penelitian [9] mengatakan bahwa penting untuk suatu perusahaan memperhatikan e-service quality karena dengan meningkatkan dan menjunjung tinggi kualitas media online maka diharapkan dapat mempertahankan pelanggan yang ada serta berusaha membuat mereka untuk tetap bertahan dalam jangka waktu yang lama sehingga dapat mengamankan loyalitas pelanggan (customer loyalty).

\section{METODOLOGI PENELITIAN}

\subsection{Jenis Penelitian}

Penelitian ini bersifat studi kasus yang hanya memiliki fokus terhadap pelanggan dari pengguna aplikasi MyTelkomsel. Metode penelitian yang dipakai oleh penulis pada penelitian ini bertujuan untuk melakukan analisis secara deskriptif. Untuk Pengumpulan data pada penelitian ini, digunakan teknik sampling yaitu dengan teknik random sampling dengan kriteria responden yang pernah menggunakan aplikasi MyTelkomsel dengan tujuan untuk menguji hipotesis yang sudah ditentukan. Penelitian ini, meneliti mengenai pengaruh dari e-service quality terhadap loyalitas pelanggan dari pengguna aplikasi MyTelkomsel

\subsection{Teknik Pengumpulan Data}

Teknik pengambilan data yang dilakukan penulis pada penelitian ini, denganmenggunakan kuesioner yang disebarkan secara online kepada 50 responden pengguna aplikasi MyTelkomsel, dengan teknik analisis menggunakan teknik analisis deskriptif. Kuesioner yang telah dibuat secara online dengan menggunakan bantuan google form kemudian akan disebarkan melalui bantuan dari media sosial seperti instagram, whatsapp, dan line sehingga memudahkan bagi para responden untuk mengisi kuisioner yang telah disediakan. Kuesioner merupakan salah satu teknik pengumpulan data yang dilakukan dengan cara memberikan beberapa pernyataan ataupun pertanyaan secaratertulis kepada responden untuk dijawab.

\subsection{Teknik Analisis Data}

Pada penelitian ini, penulis menggunakan teknik analisis deskriptif dan verifikatif. Analisis Deskriptif merupakan metode analisis statistik yang digunakan untuk menyajikan data kuantitatif dalam bentuk deskriptif, teknik ini dilakukan dengan cara melakukan perhitungan terhadap dimensi. Adapun Analisis Verifikatif yaitu teknik penelitian yang bertujuan untuk mengetahui hubungan antara dua variabel ataupun lebih untuk menguji kebenaran dari suatu hipotesis [11]. Pada penelitian ini, analisis verifikatif dilakukan dengan Regresi Linear yang merupakan salah satu jenis pendekatan untuk memodelkan hubungan antara suatu variabel dependen dengan satu ataupun lebih variabel independen. 


\section{HASIL DAN PEMBAHASAN}

Berdasarkan model penelitian yang tercantum pada Gambar 4.1 dan telah dibuat dengan acuan berasal dari variabel, dimensi dan indikator pada penelitian ini yaitu variabel pertama dengan Kualitas Pelayanan yang terdiri dari Kehandalan, Ketanggapan, Antarmuka, dan variabel kedua dengan Loyalitas Pelanggan terdiri dari Kegunaan, Pembelian Kembali, dan Rekomendasi, diharapkan dapat membantu dalam penentuan pengaruh dari setiap indicator sehingga mendapatkan hasil yang dibutuhkan pada penelitian ini.

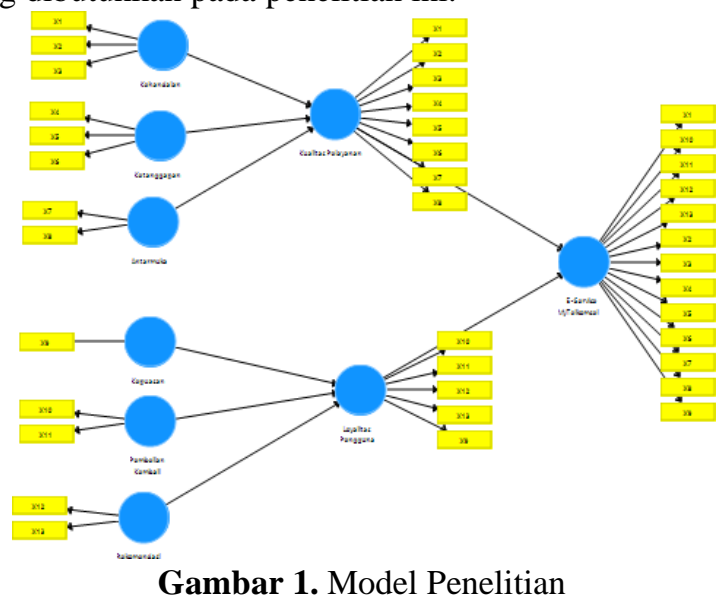

\subsection{Profil Responden}

Tabel 1. Responden Berdasarkan Jenis Kelamin

\begin{tabular}{cccccc}
\hline & & \multicolumn{2}{c}{ Jenis Kelamin } & & \\
& & Frequency & Percent & Valid Percent & Cumulative Percent \\
\hline Valid & Laki Laki & 19 & 37,3 & 37,3 & 37,3 \\
& Perempuan & 32 & 62,7 & 62,7 & 100,0 \\
& Total & 51 & 100,0 & 100,0 & \\
\hline
\end{tabular}

Tabel 1 menjelaskan bahwa dominasi responden pada penelitianini adalah perempuan dengan frekuensi sebanyak 32 responden dengan responden laki-laki sebanyak 19 responden dari total 51 responden.

Tabel 2. Responden Berdasarkan Pekerjaan

\begin{tabular}{llcccc}
\hline & & Pekerjaan & & \\
& & Frequency & Percent & Valid Percent & Cumulative Percent \\
\hline Valid & Karyawan Swasta & 1 & 2,0 & 2,0 & 2,0 \\
& Lainnya & 2 & 3,9 & 3,9 & 5,9 \\
& Mahasiswa & 47 & 92,2 & 92,2 & 98,0 \\
& PNS & 1 & 2,0 & 2,0 & 100,0 \\
& Total & 51 & 100,0 & 100,0 & \\
\hline
\end{tabular}

Berdasarkan tabel 2, dapat terlihat bahwa mayoritas responden pada penelitian ini mempunyai latar belakang pekerjaan sebagai mahasiswa dengan frekuensi sebanyak 47 responden dari total 51 responden.

Tabel 3. Responden Berdasarkan Umur

\begin{tabular}{cccccc}
\hline & & \multicolumn{3}{c}{ Umur } & \\
& Frequency & Percent & Valid Percent & Cumulative Percent \\
\hline Valid & $17-30$ Tahun & 51 & 100,0 & 100,0 & 100,0 \\
\hline
\end{tabular}

Berdasarkan tabel 3 terlihat bahwa rentang umur responden pada penelitian berada pada umur produktif dan tinggi akan kebutuhan terhadap telekomunikasi seluler dan mobile yaitu di rentang 17-30 tahun dari total total 51 responden.

\subsection{Analisis Deskriptif}

Gambaran dimensi dan indikator pada penelitian bertujuan untuk memperoleh jawaban mengenai sejauh mana respon positif yang didapatkan dan dipertimbangkan oleh responden sehingga mampu mempengaruhi loyalitas pengguna MyTelkomsel. 
Building of Informatics, Technology and Science (BITS)

Volume 3, No 3, December 2021, Page 302-311

ISSN 2684-8910 (media cetak)

ISSN 2685-3310 (media online)

DOI 10.47065/bits.v3i3.1076

\subsubsection{Gambaran Dimensi Kehandalan}

Gambaran dimensi reliability atau kehandalan digunakan bertujuan untukmemperoleh jawaban mengenai sejauh kehandalan mempengaruhi ataupundipertimbangkan oleh pengguna sebagai faktor utama dalam mempengaruhi loyalitas pengguna terhadap E-Service Quality dari MyTelkomsel.

Tabel 4. Dimensi Kehandalan (Mudah dalam pembelian paket di MyTelkomsel)

\begin{tabular}{cccccc}
\hline & Frequency & Percent $(\%)$ & Valid Percent $(\%)$ & Cumulative Percent(\%) & Score \\
\hline 2 & 2 & 3,9 & 3,9 & 3,9 & 4 \\
3 & 4 & 7,8 & 7,8 & 11,8 & 12 \\
4 & 20 & 39,2 & 39,2 & 51 & 80 \\
5 & 25 & 49 & 49 & 100 & 125 \\
Total & 51 & 100 & 100 & & 221 \\
\hline
\end{tabular}

Tabel 5. Dimensi Kehandalan (Kinerja aplikasi di My Telkomsel Baik)

\begin{tabular}{cccccc}
\hline & Frequency & Percent $(\%)$ & Valid Percent $(\%)$ & Cumulative Percent $(\%)$ & Score \\
\hline 2 & 5 & 9,8 & 9,8 & 9,8 & 10 \\
3 & 11 & 21,6 & 21,6 & 31,4 & 33 \\
4 & 24 & 47,1 & 47,1 & 78,4 & 96 \\
5 & 11 & 21,6 & 21,6 & 100 & 55 \\
Total & 51 & 100 & 100 & & 194 \\
\hline
\end{tabular}

Tabel 6. Dimensi Kehandalan (Promo di MyTelkomsel Sangat Berguna)

\begin{tabular}{|c|c|c|c|c|c|c|}
\hline & & Frequency & Percent $(\%)$ & Valid Percent $(\%)$ & Cumulative Percent(\%) & Score \\
\hline \multirow[t]{6}{*}{ Valid } & 1 & 2 & 3,9 & 3,9 & 3,9 & 2 \\
\hline & 2 & 4 & 7,8 & 7,8 & 11,8 & 8 \\
\hline & 3 & 7 & 13,7 & 13,7 & 25,5 & 21 \\
\hline & 4 & 20 & 39,2 & 39,2 & 64,7 & 80 \\
\hline & 5 & 18 & 35,3 & 35,3 & 100 & 90 \\
\hline & Total & 51 & 100 & 100 & & 201 \\
\hline
\end{tabular}

Tabel 7. Total Kualitas Pelayanan (Reliability)

\begin{tabular}{ccc}
\hline No & Pernyataan & Total \\
\hline 1 & Mudah dalam pembelian paket di MyTelkomsel & 221 \\
2 & Kinerja aplikasi di My Telkomsel Baik & 194 \\
3 & Promo di MyTelkomsel Sangat Berguna & 201 \\
& Total Akhir & 616 \\
\hline
\end{tabular}

Berdasarkan ketiga label diatas dapat ditemukan informasi bahwa terdapat pernyataan yang sangat disetujui dan sangat tidak disetujui oleh responden. Diketahui bahwa sebesar 49\% (persentase) responden atau pengguna menyatakan sangat setuju dengan pernyataan "Mudah dalam pembelian paket di MyTelkomsel" dengan total skor sebesar 221 yang artinya aplikasi MyTelkomsel terbukti handal dan dapat mempermudah pengguna.

\subsubsection{Gambaran Dimensi Ketanggapan}

Gambaran dimensi responsiveness atau ketanggapan digunakan bertujuan untuk memperoleh jawaban mengenai sejauh aplikasi MyTelkomsel tanggap terhadap permintaan pengguna sehingga nantinya dapat mempengaruhi ataupun dipertimbangkan oleh pengguna sebagai faktor utama dalam mempengaruhi loyalitas pengguna terhadap E-Service Quality dari MyTelkomsel.

Tabel 8. Dimensi Ketanggapan (Mudah dalam Menghubungi Customer Service)

\begin{tabular}{ccccccc}
\hline \multirow{4}{*}{ Valid } & & Frequency & Percent $(\%)$ & Valid Percent $(\%)$ & Cumulative Percent $(\%)$ & Score \\
\cline { 2 - 7 } & 2 & 2 & 3,9 & 3,9 & 3,9 & 4 \\
& 3 & 22 & 43,1 & 43,1 & 47,1 & 66 \\
4 & 18 & 35,3 & 35,3 & 82,4 & 72 \\
& 4 & 9 & 17,6 & 17,6 & 100 & 45 \\
& 5 & 100 & 100 & & 187 \\
\hline
\end{tabular}

Tabel 9. Dimensi Ketanggapan (Customer Services Ramah dan Sopan)

\begin{tabular}{ccccccc}
\hline & & \multicolumn{2}{c}{ Customer Services Ramah dan Sopan } & & \\
& Frequency & Percent $(\%)$ & Valid Percent $(\%)$ & Cumulative Percent $(\%)$ & Score \\
\hline Valid & 2 & 1 & 2 & 2 & 2 & 2 \\
\hline
\end{tabular}




\begin{tabular}{cccccc}
\hline & \multicolumn{2}{c}{ Customer Services Ramah dan Sopan } & & \\
& Frequency & Percent $(\%)$ & Valid Percent $(\%)$ & Cumulative Percent $(\%)$ & Score \\
\hline 3 & 20 & 39,2 & 39,2 & 41,2 & 60 \\
4 & 15 & 29,4 & 29,4 & 70,6 & 60 \\
5 & 15 & 29,4 & 29,4 & 100 & 75 \\
Total & 51 & 100 & 100 & & 197 \\
\hline
\end{tabular}

Tabel 10. Dimensi Ketanggapan (Customer Services Menanggapi Dengan Cepat)

\begin{tabular}{ccccccc}
\hline \multicolumn{2}{l}{ Customer Services Menanggapi Dengan Cepat } & & & \\
& & Frequency & Percent $(\%)$ & Valid Percent $(\%)$ & Cumulative Percent $(\%)$ & Score \\
\hline Valid & 2 & 4 & 7,8 & 7,8 & 7,8 & 8 \\
& 3 & 18 & 35,3 & 35,3 & 43,1 & 54 \\
& 4 & 15 & 29,4 & 29,4 & 72,5 & 60 \\
& 5 & 14 & 27,5 & 27,5 & 100 & 70 \\
& Total & 51 & 100 & 100 & & 192 \\
\hline
\end{tabular}

Tabel 11. Total Kualitas Layanan (Responsiveness)

\begin{tabular}{clc}
\hline No & \multicolumn{1}{c}{ Pernyataan } & Total \\
\hline 1 & Mudah dalam Menghubungi Customer Service & 187 \\
2 & Customer Services Ramah dan Sopan & 197 \\
3 & Customer Services Menanggapi Dengan Cepat & 192 \\
& Total Akhir & 576 \\
\hline
\end{tabular}

Berdasarkan ketiga tabel diatas dapat ditemukan informasi bahwa terdapat pernyataan yang sangat disetujui dan sangat tidak disetujui oleh responden. Diketahui bahwa sebesar 29,4\% (persentase) responden atau pengguna menyatakan sangat setuju dengan pernyataan "Customer Service Ramah dan Sopan" dengan total skor 197 yang artinya aplikasi MyTelkomsel terbukti responsif terhadap kendala yang dialamipengguna.

\subsubsection{Gambaran Dimensi Antarmuka Aplikasi}

Gambaran dimensi user interface atau antarmuka aplikasi digunakan bertujuan untuk memperoleh jawaban mengenai sejauh aplikasi MyTelkomsel mempunyai antarmuka yang dapat membuat pengguna nyaman ketika menggunakan aplikasi inisehingga nantinya dapat mempengaruhi ataupun di pertimbangkan oleh pengguna sebagai faktor utama dalam mempengaruhi loyalitas pengguna terhadap E-Service Quality dariMyTelkomsel.

Tabel 12. Dimensi Antarmuka Aplikasi (Menampilkan Informasi Dengan Baik)

\begin{tabular}{ccccccc}
\multicolumn{2}{l}{ Tampilan MyTelkomsel Menampilkan Informasi Dengan Baik } & & & \\
& & Frequency & Percent $(\%)$ & Valid Percent $(\%)$ & Cumulative Percent $(\%)$ & Score \\
\hline Valid & 2 & 1 & 2 & 2 & 2 & 2 \\
& 3 & 4 & 7,8 & 7,8 & 9,8 & 12 \\
& 4 & 28 & 54,9 & 54,9 & 64,7 & 112 \\
& 5 & 18 & 35,3 & 35,3 & 100 & 90 \\
& Total & 51 & 100 & 100 & & 216 \\
\hline
\end{tabular}

Tabel 13. Dimensi Antarmuka Aplikasi (Tampilan MyTelkomsel Responsif)

\begin{tabular}{ccccccc}
\hline & & \multicolumn{2}{c}{ Tampilan Telkomsel Responsif } & & \\
Valid & & Frequency & Percent $(\%)$ & Valid Percent $(\%)$ & Cumulative Percent $(\%)$ & Score \\
\hline & 1 & 2 & 3,9 & 3,9 & 3,9 & 2 \\
& 2 & 3 & 5,9 & 5,9 & 9,8 & 6 \\
& 3 & 8 & 15,7 & 15,7 & 25,5 & 24 \\
& 4 & 20 & 39,2 & 39,2 & 64,7 & 80 \\
& 5 & 18 & 35,3 & 35,3 & 100 & 90 \\
& Total & 51 & 100 & 100 & & 202 \\
\hline
\end{tabular}

Tabel 14. Total Kualitas Pelayanan (User Interface)

\begin{tabular}{ccc}
\hline & \multicolumn{1}{c}{ User Interface (Antarmuka Aplikasi) } & Total \\
\hline No & Pernyataan & 216 \\
2 & Tampilan MyTelkomsel Menampilkan Informasi Dengan Baik & 202 \\
& Tampilan Telkomsel Responsif & 418 \\
\hline
\end{tabular}


Berdasarkan ketiga tabel diatas dapat ditemukan informasi bahwa terdapatpernyataan yang sangat disetujui dan sangat tidak disetujui oleh responden. Diketahui bahwa sebesar 35,3\% (persentase) responden atau pengguna menyatakan sangat setuju dengan pernyataan "Tampilan MyTelkomsel Menampilkan Informasi Dengan Baik" dan "Tampilan Telkomsel Responsif" namun total skor tertinggi berada pada pernyataan "Tampilan Telkomsel Responsif"dengan total skor 202 yang artinya aplikasi MyTelkomsel terbukti tampilan atau user interface MyTelkomsel sangat responsif dan nyaman digunakan pengguna.

\subsubsection{Gambaran Dimensi Kepuasan dalam menggunakan Aplikasi}

Gambaran dimensi Kepuasan Dalam Menggunakan Aplikasi digunakan bertujuan untuk memperoleh jawaban mengenai sejauh mana dimensi Kepuasan Dalam Menggunakan Aplikasi dapat mempengaruhi ataupun dipertimbangkan oleh pengguna sebagai faktor utama dalam mempengaruhi loyalitas terhadap E-Service Quality dari MyTelkomsel.

Tabel 15. Dimensi Kepuasan Dalam Menggunakan Aplikasi (Keseluruhan AplikasiMyTelkomsel Baik)

\begin{tabular}{ccccccc}
\hline & \multicolumn{5}{c}{ Keseluruhan Aplikasi MyTelkomsel Baik } & \\
& & Frequency & Percent(\%) & Valid Percent(\%) & Cumulative Percent $(\%)$ & Score \\
\hline Valid & 2 & 2 & 3,9 & 3,9 & 3,9 & 4 \\
& 3 & 8 & 15,7 & 15,7 & 19,6 & 24 \\
& 4 & 26 & 51 & 51 & 70,6 & 104 \\
& 5 & 15 & 29,4 & 29,4 & 100 & 75 \\
& Total & 51 & 100 & 100 & & 207 \\
\hline
\end{tabular}

Tabel 16. Total Loyalitas Pelanggan (Kepuasan dalam menggunakan aplikasi)

\begin{tabular}{ccc}
\hline No & Pernyataan & Total \\
\hline 1 & Keseluruhan Aplikasi MyTelkomsel Baik & 207 \\
& Total Akhir & 207 \\
\hline
\end{tabular}

Berdasarkan 2 tabel diatas dapat ditemukan informasi bahwa terdapat pernyataan yang sangat disetujui dan tidak disetujui oleh responden Diketahui bahwa sebesar $80,4 \%$ (persentase) responden atau pengguna menyatakan setuju dengan pernyataan "Keseluruhan aplikasi MyTelkomsel baik" dengan total skor 207 yang artinya aplikasi MyTelkomsel terbukti dapat digunakan tanpa banyak kendala dan para responden setuju dan juga merasa puas terhadap aplikasi MyTelkomsel.

\subsubsection{Gambaran Dimensi Pembelian Kembali}

Gambaran dimensi pembelian kembali digunakan bertujuan untuk memperoleh jawaban mengenai sejauh mana dimensi pembelian kembali dapat mempengaruhi ataupun dipertimbangkan oleh pengguna sebagai faktor utama dalam mempengaruhiloyalitas terhadap E-Service Quality dari MyTelkomsel.

Tabel 17. Dimensi Pembelian Kembali (Saya akan membeli pulsa lagi)

\begin{tabular}{|c|c|c|c|c|c|c|}
\hline \multicolumn{7}{|c|}{ Saya akan membeli pulsa lagi } \\
\hline & & Frequency & Percent $(\%)$ & Valid Percent $(\%)$ & Cumulative Percent $(\%)$ & Score \\
\hline \multirow{6}{*}{ Valid } & 1 & 2 & 3,9 & 3,9 & 3,9 & 2 \\
\hline & 2 & 2 & 3,9 & 3,9 & 7,8 & 4 \\
\hline & 3 & 13 & 25,5 & 25,5 & 33,3 & 39 \\
\hline & 4 & 19 & 37,3 & 37,3 & 70,6 & 76 \\
\hline & 5 & 15 & 29,4 & 29,4 & 100 & 75 \\
\hline & Total & 51 & 100 & 100 & & 196 \\
\hline
\end{tabular}

Tabel 18. Dimensi Pembelian Kembali (Saya akan membeli paket internet kembali)

\begin{tabular}{|c|c|c|c|c|c|c|}
\hline \multicolumn{7}{|c|}{ Saya akan membeli paket internet kembali } \\
\hline & & Frequency & Percent $(\%)$ & Valid Percent $(\%)$ & Cumulative Percent(\%) & Score \\
\hline \multirow[t]{6}{*}{ Valid } & 1 & 1 & 2 & 2 & 2 & 1 \\
\hline & 2 & 2 & 3,9 & 3,9 & 5,9 & 4 \\
\hline & 3 & 5 & 9,8 & 9,8 & 15,7 & 15 \\
\hline & 4 & 19 & 37,3 & 37,3 & 52,9 & 76 \\
\hline & 5 & 24 & 47,1 & 47,1 & 100 & 120 \\
\hline & Total & 51 & 100 & 100 & & 216 \\
\hline
\end{tabular}


Tabel 19. Total Loyalitas Pelanggan (Pembelian Kembali)

\begin{tabular}{clc}
\hline No & \multicolumn{1}{c}{ Pernyataan } & Total \\
\hline 1 & Saya akan membeli pulsa lagi & 196 \\
2 & Saya akan membeli paket internet kembali & 216 \\
& Total Akhir & 412 \\
\hline
\end{tabular}

Berdasarkan 3 tabel diatas dapat ditemukan informasi bahwa terdapat pernyataan yang sangat disetujui dan sangat tidak disetujui oleh responden. Diketahui bahwa sebesar29,4\% (persentase) dan $47,1 \%$ responden atau pengguna menyatakan sangat setuju dengan pernyataan "Pembelian kembali terhadap pulsa dan paket internet" dengan total skor 412 yang artinya aplikasi MyTelkomsel terbukti bahwa banyak pelanggan yang loyal dan terus melakukan pembeli pulsa dan paket internet.

\subsubsection{Gambaran Dimensi Rekomendasi Kepada Teman}

Gambaran dimensi rekomendasi digunakan bertujuan untuk memperoleh jawabanmengenai sejauh mana dimensi rekomendasi dapat mempengaruhi ataupun dipertimbangkan oleh pengguna sebagai faktor utama dalam mempengaruhi loyalitas terhadap E-Service Quality dari MyTelkomsel.

Tabel 20. Dimensi Rekomendasi pada Teman (Saya akan merekomendasikan AplikasiMyTelkomsel kepada orang lain)

\begin{tabular}{ccccccc}
\hline \multicolumn{7}{c}{ Saya akan merekomendasikan Aplikasi MyTelkomsel kepada orang lain } \\
& & Frequency & Percent $(\%)$ & Valid Percent $(\%)$ & Cumulative Percent $(\%)$ & Score \\
\hline Valid & 1 & 1 & 2 & 2 & 2 & 3,9 \\
1 \\
& 2 & 1 & 2 & 2 & 29,4 & 2 \\
& 3 & 13 & 25,5 & 25,5 & 66,7 & 39 \\
& 4 & 19 & 37,3 & 37,3 & 100 & 76 \\
& 5 & 17 & 33,3 & 33,3 & & 85 \\
& Total & 51 & 100 & 100 & & 203 \\
\hline
\end{tabular}

Tabel 21. Dimensi Rekomendasi pada Teman (Saya mudah membuat orang lainmenggunakan aplikasi MyTelkomsel

\begin{tabular}{|c|c|c|c|c|c|c|}
\hline \multicolumn{7}{|c|}{ Saya mudah membuat orang lain menggunakan Aplikasi My Telkomsel } \\
\hline & & Frequency & Percent $(\%)$ & Valid Percent $(\%)$ & Cumulative Percent $(\%)$ & Score \\
\hline \multirow{6}{*}{ Valid } & 1 & 2 & 3,9 & 3,9 & 3,9 & 2 \\
\hline & 2 & 2 & 3,9 & 3,9 & 7,8 & 4 \\
\hline & 3 & 22 & 43,1 & 43,1 & 51 & 66 \\
\hline & 4 & 17 & 33,3 & 33,3 & 84,3 & 68 \\
\hline & 5 & 8 & 15,7 & 15,7 & 100 & 40 \\
\hline & Total & 51 & 100 & 100 & & 180 \\
\hline
\end{tabular}

Tabel 22. Total Loyalitas Pelanggan (Rekomendasi Kepada Teman)

\begin{tabular}{llcc}
\hline No & & Pernyataan & Total \\
\hline & 1 & Saya akan merekomendasikan Aplikasi MyTelkomsel kepada orang lain & 203 \\
& 2 & Saya mudah membuat orang lain menggunakan Aplikasi My Telkomsel & 180 \\
& & Total Akhir & 383 \\
\hline
\end{tabular}

Berdasarkan 3 tabel diatas dapat ditemukan informasi bahwa terdapat pernyataan yang sangat disetujui dan sangat tidak disetujui oleh responden. Diketahui bahwa sebesar 33,3\% (persentase) dan 15,7\% responden atau pengguna menyatakan sangat setuju dengan pernyataan "Rekomendasi Kepada Teman dan Membuat orang lain menggunakanaplikasi” dengan total skor 383 yang artinya aplikasi MyTelkomsel terbukti sangat mudah untuk direkomendasikan kepada teman namun sedikit kesulitan untuk membuat orang lain menggunakan aplikasi MyTelkomsel.

\subsubsection{Rekapitulasi Variabel X dan Y (Kualitas Pelayanan dan Loyalitas Pelanggan)}

Secara keseluruhan loyalitas pelanggan dapat bernilai positif jika rekomendasi dan pembelian ulang dapat diketahui pengaruhnya berdasarkan skor yang didapat dari rekapitulasi data dari responden, dimana terjadi perbandingan pada nilai-nilai tersebut sesuai dengan kriteria skor standar yang didapatkan melalui perhitungan skor ideal (sesuai dengan kriteria) dengan skor terkecil, sehingga melalui skor standar tersebut dapat diketahui daerah kontinum yang menunjukan wilayah ideal dari variabel. Langkah yang dapat dilakukan dalam menyusun rekapitulasi variabel Loyalitas Pelanggan adalah melalui tabel di bawah ini. 
Building of Informatics, Technology and Science (BITS)

Volume 3, No 3, December 2021, Page 302-311

ISSN 2684-8910 (media cetak)

ISSN 2685-3310 (media online)

DOI 10.47065/bits.v3i3.1076

Tabel 23. Rekapitulasi Skor Penilaian Gambaran Kualitas Pelayanan

\begin{tabular}{clccc}
\hline \multicolumn{2}{c}{ Rekapitulasi Skor Penilaian Gambaran Kualitas Pelayanan } & & \\
No & Dimensi & Skor Total & Rata Rata Skor & $\%$ \\
\hline 1 & Reliability (Kehandalan) & 616 & 205 & $38,3 \%$ \\
2 & Responsiveness (Ketanggapan) & 576 & 192 & $35,8 \%$ \\
3 & User Interface (Antarmuka Aplikasi) & 418 & 209 & $26,0 \%$ \\
\multicolumn{2}{r}{ Kualitas Pelayanan } & 1610 & 606 & $100,0 \%$ \\
\hline
\end{tabular}

Berdasarkan tabel 23 yang menjelaskan mengenai rekapitulasi skor dari dimensi-dimensi kualitas pelayanan yang akan mempengaruhi loyalitas pelanggan. Dimensi yang memiliki skor rata rata tertinggi adalah dimensi reliability (Kehandalan) sebesar 205 dengan persentase 38,3\%.

Tabel 24 Rekapitulasi Skor Penilaian Gambaran Loyalitas Pelanggan

\begin{tabular}{|c|c|c|c|c|}
\hline \multicolumn{5}{|c|}{ Rekapitulasi Skor Penilaian Gambaran Loyalitas Pelanggan } \\
\hline No & Dimensi & Skor Total & Rata Rata Skor & $\%$ \\
\hline 1 & Kepuasan Dalam Menggunakan Aplikasi & 207 & 207 & $20,7 \%$ \\
\hline 2 & Pembelian Kembali & 412 & 206 & $41,1 \%$ \\
\hline 3 & Rekomendasi Kepada Tman & 383 & 192 & $38,2 \%$ \\
\hline & Kualitas Pelayanan & 1002 & 605 & $100,0 \%$ \\
\hline
\end{tabular}

Berdasarkan tabel 24 yang menjelaskan mengenai rekapitulasi skor dari dimensi-dimensi loyalitas pelanggan secara langsung. Dimensi yang memiliki skor rata tertinggi adalah dimensi "kepuasaan dalam menggunakan aplikasi sebesar 207 dengan persentase $20,7 \%$.

\subsection{Analisis Verifikatif}

Analisis regresi merupakan analisis yang digunakan untuk mempelajari pengaruh variabel bebas terhadap variabel terikat. Pengolahan serta hasil dari analisis regresi linearadalah sebagai berikut:

Tabel 25. Variabel Entered or Removed

\begin{tabular}{lll}
\hline $\begin{array}{l}\text { Variables Entered/Removeda } \\
\text { Model Variables Entered }\end{array}$ & Variables Removed & Method \\
\hline 1 & Kualitas Layanan \\
& & \\
& & \\
& & \\
a Dependent Variable: Loyalitas Pelanggan \\
b All requested variables entered.
\end{tabular}

Tabel 26. Model Summary R Square

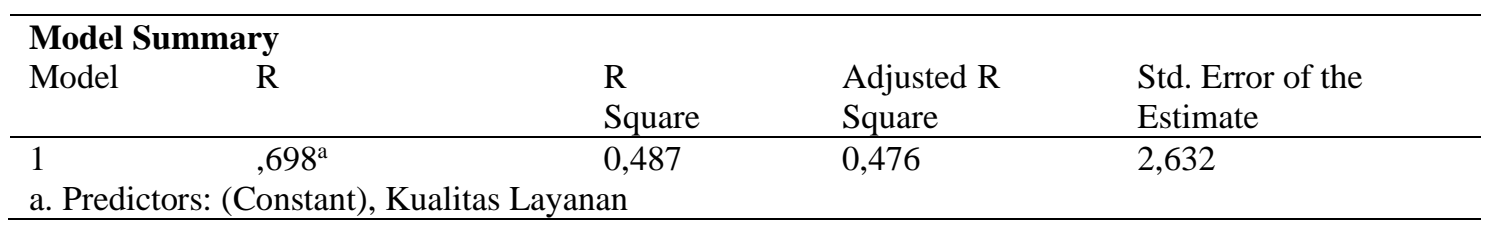

Tabel 27. Uji ANOVA

\begin{tabular}{|c|c|c|c|c|c|c|}
\hline \multicolumn{7}{|c|}{$\mathrm{ANOVA}^{\mathrm{a}}$} \\
\hline Model & & Sum of Squares & $\mathrm{df}$ & Mean Square & $\mathrm{F}$ & Sig. \\
\hline \multirow[t]{3}{*}{1} & Regression & 322,157 & 1 & 322,157 & 46,498 &, $000 \mathrm{~b}$ \\
\hline & Residual & 339,491 & 49 & 6,928 & & \\
\hline & Total & 661,647 & 50 & & & \\
\hline
\end{tabular}

a Dependent Variable: Loyalitas Pelanggan

b Predictors: (Constant), Kualitas Layanan

Tabel 28. Nilai Coefficients

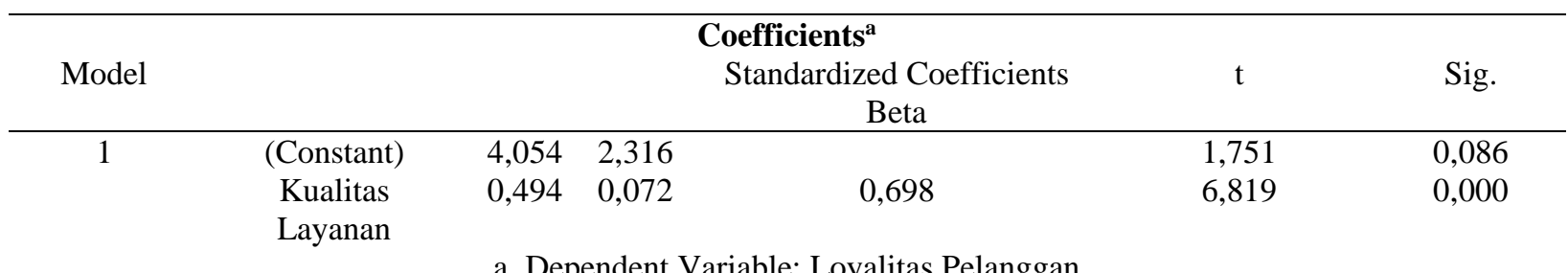


Dari penelitian dapat dilihat bahwa hasil uji mempunyai berbagai hasil sesuai dengan jenis uji yang dilakukan yaitu regresi linear, dimana penelitian dan uji ini sendiri bertujuan untuk (1) mengetahui gambaran dari kualitas pelayanan dari aplikasitelekomunikasi seluler yaitu MyTelkomsel, (2) melihat gambaran variabel loyalitas pelanggan pada aplikasi MyTelkomsel, (3) melihat pengaruh dari kualitas layanan terhadap loyalitas pelanggan MyTelkomsel.

\section{KESIMPULAN}

Kesimpulan yang didapat pada penelitian ini adalah variabel kualitas pelayanan (E-Service Quality) yang diuji terhadap dimensi Reliability (Kehandalan) yang terdiri dari 3 bagian, dimensi Responsiveness (Ketanggapan) juga terdapat 3 bagian, dan User Interface (Antarmuka Aplikasi). Dari hasil uji skor tertinggi ada pada User Interface (Antarmuka Aplikasi) dengan rata rata skor 209. Kedua untuk variabel loyalitas pelanggan diuji terhadap dimensi kepuasan dalam menggunakan aplikasi hanya memiliki 1 bagian, pembelian kembali memiliki 2 bagian, rekomendasi kepada teman juga memiliki 2 bagian. Dari hasil uji skor tertinggi ada pada kepuasan dalam menggunakan aplikasi dengan rata rata skor 207. Hasil akhir yang didapat dari penelitian ini adalah bahwa terdapat pengaruh positif dan signifikan yang mana dapat dilihat dari hasil analisis pada $e$-service quality yang sangat berpengaruh dalam loyalitas pelanggan bertahan dalam menggunakan aplikasi MyTelkomsel pada saat kualitas pelayanan terus ditingkatkan. Sehingga Pelanggan akan setia untuk menggunakannya.

\section{REFERENCES}

[1] N. M. S. Anggraeni and N. N. K. Yasa, "E-Service Quality Terhadap Kepuasan Dan Loyalitas Pelanggan Dalam Penggunaan Internet Banking," J. Keuang. dan Perbank., vol. 16, no. 2, pp. 293-306, 2012, [Online]. Available: http://jurkubank.wordpress.com.

[2] M. R. Alfajri and A. Wardhana, "Pengaruh Customer Relationship Management (crm) Terhadap Loyalitas Pelanggan Tiket. com (survey Pada Pengguna Tiket. com Di Kota Bandung)," eProceedings Manag., vol. 7, no. 3, 2020.

[3] N. Laely and D. Rosita, "Pengaruh Customer Relationship Marketing dan Kualitas Layanan Terhadap Kepuasan: Studi Konsumen McDonald's Kediri,” EKONIKA J. Ekon. Univ. Kadiri, vol. 5, no. 2, pp. 224-242, 2020.

[4] M. D. D. Akhmadi and E. Martini, "Pengaruh E-Serivce Quality Terhadap Kepuasan Dan Loyalitas Pelanggan Aplikasi OVO,” J. Mitra Manaj., vol. 4, no. 5, pp. 708-720, May 2020, doi: 10.52160/ejmm.v4i5.385.

[5] T. T. Haria and M. R. Mulyandi, "Pengaruh E-Service Quality terhadap E-Satisfaction pada Pengguna Aplikasi Mobile,” vol. 6, no. 1, pp. 135-140, 2019, doi: 10.33510/slki.2019.135-140.

[6] F. I. Hutama and R. R. R. F. Hutami, "Pengaruh E-Service Quality Terhadap Kepuasan Dan Loyalitas Pelanggan Pada Jd . Id ( Studi Kasus Pada Pelanggan Di," e-Proceeding Manag., vol. 8, no. 4, pp. 3194-3201, 2021, [Online]. Available: https://openlibrarypublications.telkomuniversity.ac.id/index.php/management/article/view/15308.

[7] L. I. Wahyuni, S. Wahyuni, and J. Widodo, "Pengaruh Kepuasan Pelanggan Terhadap Loyalitas Merek Pada Kartu Prabayar Simpati Telkomsel," J. Pendidik. Ekon. J. Ilm. Ilmu Pendidikan, Ilmu Ekon. dan Ilmu Sos., vol. 12, no. 2, 2018, doi: 10.19184/jpe.v12i2.8560.

[8] K. V. W. Atmaja, I. N. Sujana, and K. R. Suwena, "Pengaruh Kualitas Pelayanan dan Kepuasan Terhadap Loyalitas Pelanggan pada PT. Pos Cabang Singaraja," J. Pendidik. Ekon. Undiksha, vol. 10, no. 1, 2019, doi: 10.23887/jjpe.v10i1.20039.

[9] H. Jonathan, "Analisis Pengaruh E-Service Quality terhadap Customer Satisfaction yang Berdampak pada Customer Loyalty PT Bayu Buana Travel Tbk," The Winners, vol. 14, no. 2, pp. 104-112, 2013.

[10] M.-H. Chen, K.-M. Tsai, Y.-C. Hsu, and K.-Y. Lee, "E-Service Quality Impact On Online Customer's Perceived Value And Loyalty," China-USA Bus. Rev., vol. 12, no. 5, 2013.

[11] T. A. Susnita, "Pengaruh Kualitas Pelayanan dan Kepuasan Pelanggan Terhadap Loyalitas Pelanggan pada Hotel Libra Kadipaten Kabupaten Majalengka,” Juripol (Jurnal Institusi Politek. Ganesha Medan), vol. 3, no. 1, 2020, doi: 10.33395/juripol.v3i1.10485.

[12] M. Karina, "Pengaruh E-servicescape Online Marketplace Shopee pada Perceived Value dan Kepuasan Pelanggan, serta Dampaknya terhadap Loyalitas Pelanggan,” J. Maksipreneur Manajemen, Koperasi, dan Entrep., vol. 9, no. 1, 2019, doi: 10.30588/jmp.v9i1.534.

[13] D. Rintasari and N. Farida, "Pengaruh E-Trust dan E-Service Quality terhadap E-Loyalty melalui E-Satisfaction (Studi pada Pengguna Situs E-Commerce C2C Shopee di Kabupaten Sleman)," J. Ilmu Adm. Bisnis, vol. 9, no. 4, pp. 539-547, 2020.

[14] F. Ulum and R. Muchtar, "Pengaruh E-Service Quality Terhadap E-Customer Satisfaction Website Start-Up Kaosyay," J. Tekno Kompak, vol. 12, no. 2, pp. 68-72, 2018.

[15] E. H. Pratama, A. Santoso, and E. Girahani, "Pengaruh Kualitas Layanan Pada Warung Internet I-Cafe Terhadap Loyalitas Pelanggan Melalui Kepuasan Pelanggan Di Kota Blitar," JIMEK J. Ilm. Mhs. Ekon., vol. 1, no. 2, 2019, doi: 10.30737/jimek.v1i2.311.

[16] R. M. Al-dweeri, Z. M. Obeidat, M. A. Al-dwiry, M. T. Alshurideh, and A. M. Alhorani, "The Impact Of E-Service Quality And E-Loyalty On Online Shopping: Moderating Effect Of E-Satisfaction And E-Trust,” Int. J. Mark. Stud., vol. 9, no. 2, pp. 92-103, 2017.

[17] A. Arzaq Akbar and T. Djatmiko, "Pengaruh E-Service Quality Terhadap E-Customer Satisfaction Dan E-Customer Loyalty Pada Lazada.Co.Id the Impact of E-Service Quality Towards E-Customer Satisfaction and E-Customer Loyalty in Lazada.Co.Id," vol. 3, no. 1, pp. 142-150, 2016.

[18] D. Henriawan, "Pengaruh kualitas pelayanan dan kepuasan pelanggan terhadap loyalitas pelanggan (Studi Kasus Pada Toko Cabang Mufin Wilayah Bandung Timur)," Copetition, vol. VI, no. 2, 2019. 
[19] H. Permana and T. Djatmiko, "Analisis Pengaruh Kualitas Layanan Elektronik (E-Service Quality) Terhadap Kepuasan Pelanggan Shopee Di Bandung," SOSIOHUMANITAS, vol. 20, no. 2, pp. 64-78, 2018.

[20] W. Sastika, "Analisis Kualitas Layanan dengan Menggunakan E-service Quality untuk Mengetahui Kepuasan Pelanggan Belanja Online Shoppe (Studi Kasus: Pelanggan Shopee di Kota Bandung 2017)," IKRA-ITH Hum. J. Sos. dan Hum., vol. 2 , no. 2, pp. 69-74, 2018.

[21] W. S. Dewobroto, "Pengaruh Digital Loyalty Program Terhadap Kepuasan Dan Loyalitas Pelanggan Studi Kasus Tokopedia," J. Pemasar. Kompetitif, vol. 4, no. 1, 2020, doi: 10.32493/jpkpk.v4i1.5459.

[22] Masadah, Asngadi, and C. Triono Singgih, "Pengaruh Kualitas Layanan Terhadap Loyalitas Nasabah Tabungan Bank Syariah Di Kabupaten Jombang Yang Dimediasi Variabel Kepuasan,” J. Tabarru' Islam. Bank. Financ., vol. 3, no. 2, 2020, doi: 10.25299/jtb.2020.vol3(2).5808.

[23] R. A. Raidah and S. F. Wibowo, "Analisis Pengaruh E-Service Quality Dan Perceived Service Value Terhadap Kepuasan Pelanggan Tokopedia," JRMSI-Jurnal Ris. Manaj. Sains Indones., vol. 10, no. 1, pp. 148-166, 2019.

[24] L. A. Ndun, "Analisis Pengaruh E-Service Quality Dan Perceived Value Terhadap Kepuasan Pelanggan Dan Loyalitas Pelanggan Layanan Internet Indihome," J. Manaj. Bisnis dan Kewirausahaan, vol. 3, no. 1, 2019, doi: 10.24912/jmbk.v3i1.4929.

[25] H. Siagian and E. Cahyono, "Analisis Website Quality, Trust Dan Loyalty Pelanggan Online Shop,” J. Manaj. Pemasar., vol. 8, no. 2, pp. 55-61, 2014, doi: 10.9744/pemasaran.8.2.55-61.

[26] Rohwiyati, "Pengaruh Kualitas Pelayanan Ojol Maxim Terhadap Loyalitas Pelanggan Melalui Corporate Image Sebagai Variabel Mediasi (Survey Pada Mahasiswa di Surakarta)," J. Ekon. BISNIS DAN KEWIRAUSAHAAN, vol. 9, no. 2, 2020 doi: 10.47942/iab.v9i2.517.

[27] S. W. Hati and A. Juliati, “Analisis Pengaruh Logistics Service Quality Terhadap Kepuasan Dan Loyalitas Penlanggan Pada Perusahaan Logistik Jalur Nugraha Ekakurir (JNE),” J. AKUNTANSI, Ekon. dan Manaj. BISNIS, vol. 7, no. 2, 2019, doi: 10.30871/jaemb.v7i2.1592.

[28] D. S. . Wuisan, "Pengaruh E-Service Quality Dan Food Quality Terhadap Customer Loyalty Pengguna GoFood Indonesia Yang Dimediasi Oleh Perceived Value Dan Customer Satisfaciton," JMBI UNSRAT (Jurnal Ilm. Manaj. Bisnis dan Inov. Univ. Sam Ratulangi)., vol. 8, no. 1, 2021, doi: 10.35794/jmbi.v8i1.33851.

[29] N. Ekawaty, R. L. Batu, and W. MM, “Analisis Pengaruh Kualitas Pelayanan Terhadap Loyalitas Pelanggan Situs Booking Online Traveloka," J. Manaj. Bisnis Kreat., vol. 4, no. 2, 2019, doi: 10.36805/manajemen.v4i2.558.

[30] A. Juhria, N. Meinitasari, F. I. Fauzi, and A. Yusuf, "Pengaruh E-Service Quality Terhadap Kepuasan Pelanggan Di Aplikasi E-Commerce Shopee," J. Manaj., vol. 13, no. 1, pp. 55-62, 2021.

[31] S. Behjati, M. Nahich, and S. N. Othaman, "Interrelation Between E-Service Quality and E-satisfaction And Loyalty," Eur. J. Bus. Manag., vol. 4, no. 9, pp. 75-85, 2012.

[32] C. A. Wijayanti, "Pengaruh Kualitas Layanan Dan Kepuasan Pelanggan Pada Loyalitas Pelanggan Di Restoran Pizza EBirra," Klabat J. Manag., vol. 1, no. 1, 2020, doi: 10.31154/kjm.v1i1.447.11-42.

[33] H. Haryantini, "Pengaruh Citra Merek dan Promosi Terhadap Loyalitas Pelanggan Go-Jek di Stasiun Depok Jawa Barat,” J. Pemasar. Kompetitif, vol. 3, no. 1, 2019, doi: 10.32493/jpkpk.v3i1.3604.

[34] C. Hongdiyanto, M. Padmalia, G. G. Gosal, and D. V. Wahanadie, "The Influence Of E-Service Quality And E-Recovery Towards Repurchase Intention On Online Shop In Surabaya: The Mediating Role Of Customer Loyalty," DeReMa (Development Res. Manag. J. Manaj., vol. 15, no. 2, 2020, doi: 10.19166/derema.v15i2.2440.

[35] R. P. Baistama and E. Martini, "E-Service Quality Effect on Customer Satisfaction and Loyalty in," vol. 8, no. 4, pp. 31823193, 2021.

[36] E. Veronika, B. AY, and I. Aryati, "Pengaruh Brand Image, Harga, Dan Produk Terhadap Loyalitas Pelanggan Martabak Brengos(D’Mrongos) Solo,” J. Manaj. dan Keuang., vol. 7, no. 2, 2018, doi: 10.33059/jmk.v7i2.487.

[37] T. Citra, I. M. Sukresna, and J. Sugiharto, "Analisis Pengaruh Kualitas Produk, Kualitas Layanan Dan Kemampuan Menjual Terhadap Loyalitas Pelanggan (Studi Pada Percetakan Jadi Jaya Group, Semarang),” J. Sains Pemasar. Indones. (Indonesian J. Mark. Sci., vol. 18, no. 1, 2019, doi: 10.14710/jspi.v18i1.1-14.

[38] D. Wahyuni, "Pengaruh E-Customer Relationship Management (E-CRM) dan E-Service Quality terhadap E-Customer Satisfaction serta Dampaknya terhadap E-Customer Loyalty.” Fakultas Ekonomi dan Bisnis uin jakarta.

[39] U. B. Haryoko and C. Centia, "Pengaruh Kualitas Pelayanan Dan Kepuasan Pelanggan Terhadap Loyalitas Pelanggan Pada Ranch 99 Market Pesanggrahan Kembangan Jakarta Barat," J. Ekon. Ef., vol. 2, no. 1, 2019, doi: 10.32493/jee.v2i1.3513.

[40] G. Gupron, "Analisis Kepuasan Konsumen Melalui E-Service Quality Terhadap Keputusan Pembelian Daring Di Aplikasi Bukalapan.com (Studi Pada Mahasiswa Universitas Batanghari Jambi),” J. Manaj. Pendidik. dan Ilmu Sos., vol. 1, no. 1, pp. 337-348, 2020. 